\title{
An observational study of the evolution of the atmospheric boundary-layer over Cabo Frio, Brazil
}

\author{
S. H. Franchito ${ }^{1}$, V. Brahmananda Rao ${ }^{1}$, T. O. Oda ${ }^{2}$, and J. C. Conforte ${ }^{1}$ \\ ${ }^{1}$ Centro de Previsão de Tempo e Estudos Climáticos, CPTEC/INPE Instituto Nacional de Pesquisas Espaciais, INPE CP 515, \\ 12245-970, São José dos Campos, SP, Brazil \\ ${ }^{2}$ Instituto de Estudos do Mar Almirante Paulo Moreira Rua Kioto, 253, 28930-000, Arraial do Cabo - RJ - Brazil
}

Received: 4 October 2006 - Revised: 23 March 2007 - Accepted: 9 August 2007 - Published: 29 August 2007

\begin{abstract}
The effect of coastal upwelling on the evolution of the atmospheric boundary layer (ABL) in Cabo Frio (Brazil) is investigated. For this purpose, radiosounding data collected in two experiments made during the austral summer (upwelling case) and austral winter (no upwelling case) are analysed. The results show that during the austral summer, cold waters that crop up near the Cabo Frio coast favour the formation of an atmospheric stable layer, which persists during the upwelling episode. Due to the low SSTs, the descending branch of the sea-breeze circulation is located close to the coast, inhibiting the development of a mixed layer mainly during the day. At night, with the reduction of the land-sea thermal contrast the descending motion is weaker, allowing a vertical mixing. The stable ABL favours the formation of a low level jet, which may also contribute to the development of a nocturnal atmospheric mixed layer. During the austral winter, due to the higher SSTs observed near the coast, the $\mathrm{ABL}$ is less stable compared with that in the austral summer. Due to warming, a mixed layer is observed during the day. The observed vertical profiles of the zonal winds show that the easterlies at low levels are stronger in the austral summer, indicating that the upwelling modulates the sea-breeze signal, thus confirming model simulations.
\end{abstract}

Keywords. Meteorology and atmospheric dynamics (Climatology; Ocean-atmosphere interactions) - Oceanography: physical (Air-sea interactions)

\section{Introduction}

During the austral summer and spring seasons, negative sea surface temperature (SST) anomalies caused by winddriven coastal upwelling are present along part of the Brazilian southeast continental shelf, particularly near Cabo Frio

Correspondence to: $\mathrm{S}$. H. Franchito

(fran@cptec.inpe.br) $\left(22^{\circ} 59^{\prime} \mathrm{S}, 42^{\circ} 02^{\prime} \mathrm{W}\right)$. Figure 1a shows a NOAA-12 AVHRR satellite image that illustrates the presence of cold waters in this region. From early September through late April the atmospheric circulation over the Cabo Frio region is strongly influenced by the large-scale South Atlantic high pressure center which makes the prevailing winds blow from the northeast with a large component parallel to the coast. This favours the occurrence of coastal upwelling in the region. Modelling studies have shown the role of the surface winds on the upwelling in the region (Castelao and Barth, 2006; Castelao et al., 2004; Carbonel, 2003). During the fall and winter seasons, stronger and more frequent cold fronts pass by the region, provoking a change in direction of the wind. The surface winds rotate counterclockwise and blow for few days from the southern quadrant, inhibiting the upwelling (Dourado and Oliveira, 2000; Gonzalez-Rodrigues et al., 1992; Stech and Lorenzzetti, 1992). The seasonality of the Cabo Frio upwelling seems to be associated with the onshore/offshore seasonal migration of the South Atlantic Central Water (SACW). Several studies have shown that the SACW is the source of cold waters that crop up near the coast in this region (Campos et al., 1995; Gaeta et al., 1994; Valentin et al., 1987; Valentin, 1984).

The coastal upwelling has an ecological impact on the Cabo Frio region. Since the surface layers of this region are dominated by warm waters of a tropical origin the coastal upwelling plays a significant role in the nutrient enrichment and sustainment of the regional fisheries productivity (Matsuura, 1998, 1996). Many studies have been done to identify, understand and record the physical, chemical, hydrological, biological and geological processes concerning the coastal upwelling in this region (Laslands et al., 2006; De Leo and Pires-Vanin, 2006; Voloch and Solé-Cava, 2005; David et al., 2005; and many others).

Besides its ecological impact on the region the upwelling also affects the local climate. The region of Cabo Frio is influenced by the sea-breeze circulation. These local winds

Published by Copernicus Publications on behalf of the European Geosciences Union. 
play an important role in determining the regional climate because of their influence on the characteristic air flow, precipitation, humidity and pollutant transport. Since the coastal upwelling increases the horizontal temperature differences the sea breeze is stronger in the region. Results from model simulations indicate that there is a positive feedback between sea-breeze and coastal upwelling at Cabo Frio. The seabreeze is intensified by the enhancement of the land-sea temperature gradient, due to the upwelling of cold water, and the costal upwelling is enhanced by the intensification of the prevailing wind caused by the sea-breeze (Rodrigues and Lorenzzetti, 2001; Franchito et al., 1998).

While most of the studies are focused on the oceanographic and ecological aspects of the coastal upwelling at Cabo Frio, only a few studies are devoted to investigate its climatic impact on the local circulation. Although Brazil is a huge country with a long coast, the research in the area of marine meteorology outside the tropics is only just starting and it is mainly concentrated in the analysis of time series data of surface winds and SST. The strongest effects on local climate are due to changes in the sea-breeze circulation that occur in the atmospheric boundary-layer (ABL). In the particular case of the Cabo Frio region very few efforts have been devoted to the understanding of the ABL behaviour. Dourado and Oliveira (2000) examined the evolution of the marine ABL during an event of cold front passage. They noted a typical inversion of the wind from northeast to southwest, followed by the warming of the ocean surface due to the subsidence of SACW and the southwest wind advection of a deep atmospheric mixed layer from the continent towards the ocean. In the years 1995 and 1996, we conducted a field experiment and data from radiosoundings were collected for the austral summer (upwelling) and austral winter (no upwelling) conditions at the Cabo Frio region. Since there are no other radiosounding data near Cabo Frio, the data set obtained in the two experiments constitutes an important data source, providing new and useful information about the behaviour of the ABL in the region. The purpose of the present paper is to analyse the vertical profiles of temperature, humidity, and wind, in order to investigate the effects of the coastal upwelling on the evolution of the ABL in the Cabo Frio region.

\section{Description of the experiments}

Two experiments were conducted at the Cabo Frio coast. In the first one, the radiosondes were launched from 9-12 January 1995, which corresponds to austral summer conditions (favourable for the occurrence of coastal upwelling); in the second experiment the radiosounding data were collected from 5 to 9 August 1996, corresponding to austral winter conditions (no upwelling conditions). In order to obtain good information about the ABL behaviour during the day the ra- diosondes were launched at different times in different days (see Table 1).

The radiosounding system used to collect the data was the MARWIN (VAISALA). It is composed basically of a reception system of temperature, pressure and humidity data. The soundings were of the RS80-15N type, with the following sensors: an aneroide capsule with $0.1 \mathrm{hPa}$ resolution, with an accuracy of $0.5 \mathrm{hPa}$; temperature sensor with a $0.1^{\circ} \mathrm{C}$ resolution and humidity sensor with an accuracy $<3 \%$. In addition, the soundings used the OMEGA system, which had several stations over the globe. These stations provided data of the position relative to the sounding, allowing for the calculation of the magnitude and direction of the wind. Although it was useful system to determine the winds, the OMEGA system was stopped in 1997.

\section{Synoptic situation}

On 9 January 1995 the atmospheric circulation was favourable for the outcrop of cold waters near the Cabo Frio coast, due to the prevailing northeast winds. This situation was altered by the passage of a cold front from 10 January to 11 January 1995 (Fig. 2a), which changed the wind direction. The occurrence of a cold front during the austral summer is less frequent than in the austral winter. However, sometimes it may organize tropical convection, which persists for 4 days or more, characterizing SACZ (South Atlantic Convergence Zone) episodes. Table 2 shows the values of the temperature of water, which was pumped by the cooling system of Companhia Nacional de Álcalis (situated in Cabo Frio region) during the period of the experiment. The measurement was made after the water passed by a tube of 2-km in length. Thus, these values were not equal to those of the SST because the water was heated during its passage by the tube. However, as can be seen in Table 2, the values of water temperature were within the limits of SACW (less than $20^{\circ} \mathrm{C}$ ), except on 12 January 1995 . From 11 January to 12 January 1995 the water temperature increased due to the influence of a cold front in the region: after the end of the experiment there was a decrease in SST, returning to the upwelling conditions, as can be seen in Fig. 1a. We have not shown a figure containing the NOAA-12 AVHRR satellite image for 9 January 1995 because there were cirrus clouds in the Cabo Frio region, which complicates the visualization of the negative anomalies of SST.

During 5-9 August 1996 there were clear weather conditions (see Fig. 2b, which shows a NOAA satellite image for 9 August 1996). This period was characterized by the absence of coastal upwelling, as shown by the NOAA-12 AVHRR satellite image (Fig. 1b). 


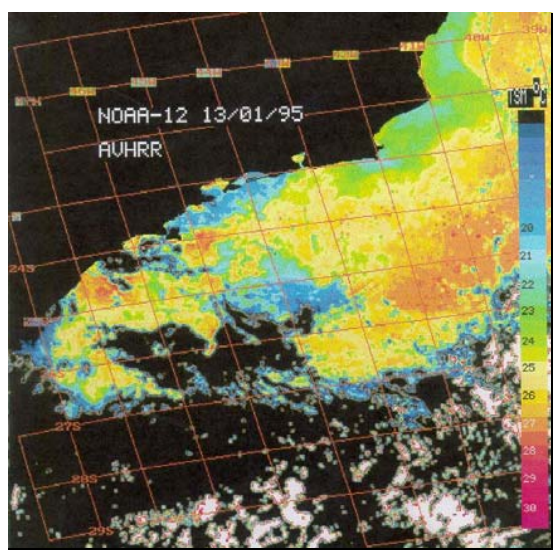

(a)

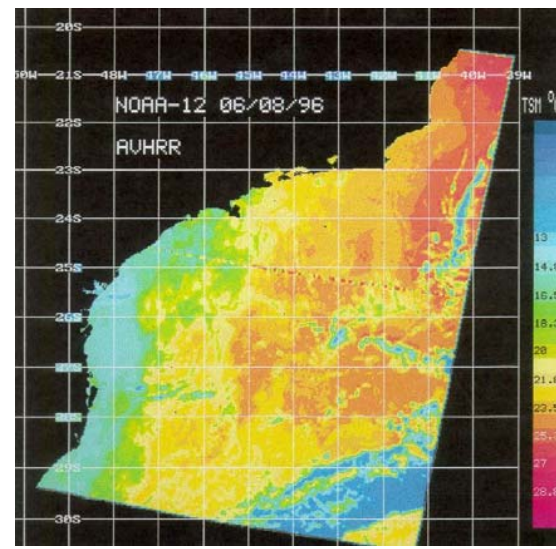

(b)

Fig. 1. NOAA-12 AVHRR satellite image for: (a) day 13 January 1995, showing the coastal upwelling in the Cabo Frio region, and (b) day 6 August 1996, when the upwelling is not present in the region (values of SST higher than $23.5^{\circ} \mathrm{C}$ ).

Table 1. Days and hours (LT) when the radiosondes were launched in the COINT Project.

\begin{tabular}{|c|c|c|c|c|c|c|c|c|c|}
\hline DAY & 9 January 1995 & 10 January 1995 & 11 January 1995 & 12 January 1995 & 5 August 1996 & 6 August 1996 & 7 August 1996 & 8 August 1996 & 9 August 1996 \\
\hline \multirow[t]{7}{*}{ LT } & $12: 00$ & 08:00 & 08:00 & 08:00 & 19:00 & 09:00 & 08:00 & 06:00 & 13:00 \\
\hline & $16: 00$ & 14:00 & 10:00 & 11:00 & & 14:00 & $13: 00$ & 09:00 & $15: 00$ \\
\hline & 18:00 & $16: 00$ & $15: 00$ & $14: 00$ & & 15:00 & $15: 00$ & $12: 00$ & $17: 00$ \\
\hline & $22: 00$ & 20:00 & $17: 00$ & $16: 00$ & & 18:00 & & $15: 00$ & \\
\hline & & & 19:00 & 18:00 & & & & 18:00 & \\
\hline & & & 21:00 & 20:00 & & & & 19:00 & \\
\hline & & & & $24: 00$ & & & & 20:00 & \\
\hline
\end{tabular}

\section{Evolution of the ABL in Cabo Frio region}

\subsection{Upwelling case}

In this section the evolution of the $\mathrm{ABL}$ is examined using the radiosounding data collected from 9 to 12 January 1995. Figures $3 \mathrm{a}-\mathrm{d}$ show the vertical profiles of the virtual potential temperature $\left(\theta_{v}\right)$, mixing ratio $\left(\mathrm{r}_{w}\right)$, zonal wind $(\mathrm{u})$ and meridional wind (v) component, respectively, on 9 January 1995. Taking into account the coastline orientation in the region of Cabo Frio (Figs. 1a and b) and the fact that the prevailing wind blows from northeast in the upwelling case, the larger the inclination of the observed wind in the zonal direction, the stronger the sea breeze will be. As can be seen in Fig. 3c, at low levels the easterly zonal wind component increased during the day, reaching higher values $\left(13 \mathrm{~m} \mathrm{~s}^{-1}\right)$ around 18:00 LT (Local Time), indicating an enhancement of the sea-breeze circulation. From $600 \mathrm{~m}$ to $1200 \mathrm{~m}$ a return flow can be noted at 16:00 LT. The meridional component was always from the north in the entire ABL. The highest values of $\mathrm{v}$ occurred during the night when the sea-breeze circulation was weak (Fig. 3d). As can be seen in Figs. 3c, and $3 \mathrm{a}$, there was the formation of a low level jet (LLJ) in
Table 2. Temperature of the water $\left({ }^{\circ} \mathrm{C}\right)$, which was pumping by the cooling system of Companhia Nacional de Álcalis (situated in Cabo Frio region) in days 9-12 January 1995.

\begin{tabular}{cc}
\hline Day & Water temperature $\left({ }^{\circ} \mathrm{C}\right)$ \\
\hline 9 January 1995 & 18.0 \\
10 January 1995 & 18.0 \\
11 January 1995 & 19.0 \\
12 January 1995 & 22.0 \\
\hline
\end{tabular}

a stable ABL (Blackadar, 1957). Figure 3a shows the presence of a stable layer at low levels in the four soundings. However, a superadiabatic layer was present from the surface up to $50 \mathrm{~m}$ in the first two soundings (at 12:00 LT and 16:00 LT). At 18:00 LT a stable vertical $\theta_{v}$ profile was observed in the entire ABL. At 22:00 LT there was an atmospheric mixed layer with the top around 100-200 m. The absence of a mixed layer during the day may be associated with the fact that the region was affected by the descending branch of the sea-breeze circulation, due to the proximity of the upwelling cold waters. At night, with the radiative cooling of 


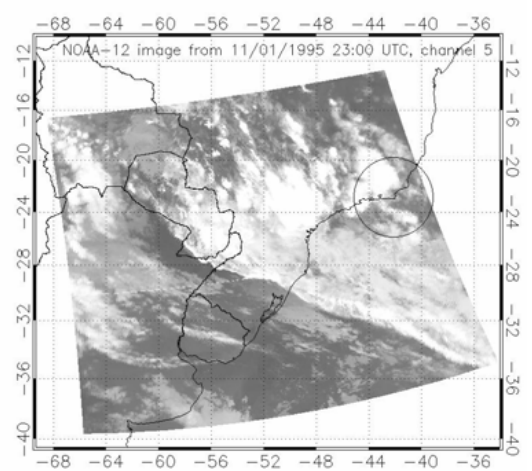

(a)

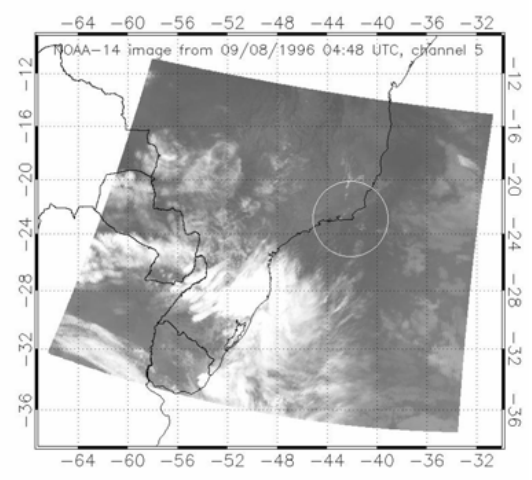

(b)

Fig. 2. NOAA satellite image for: (a) 10 January 1995, and (b) 9 August 1996. The circles indicate the location of the Cabo Frio region.

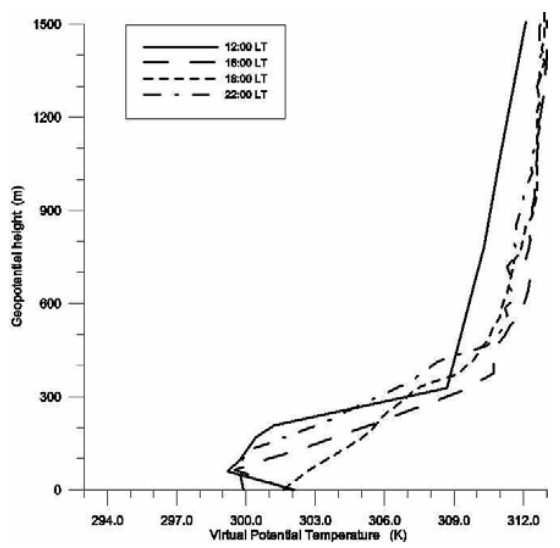

(a)

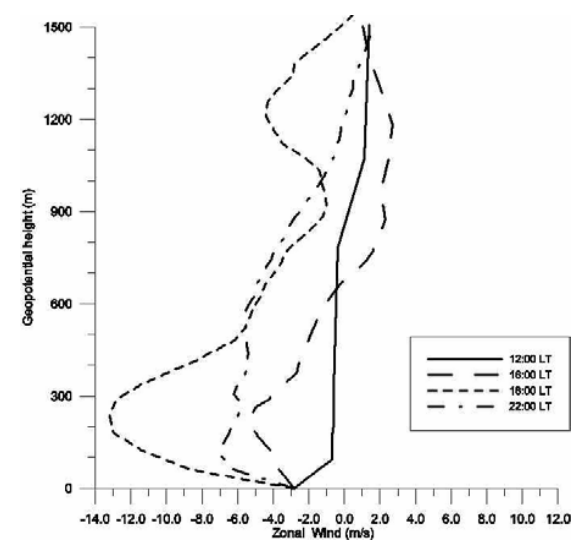

(c)

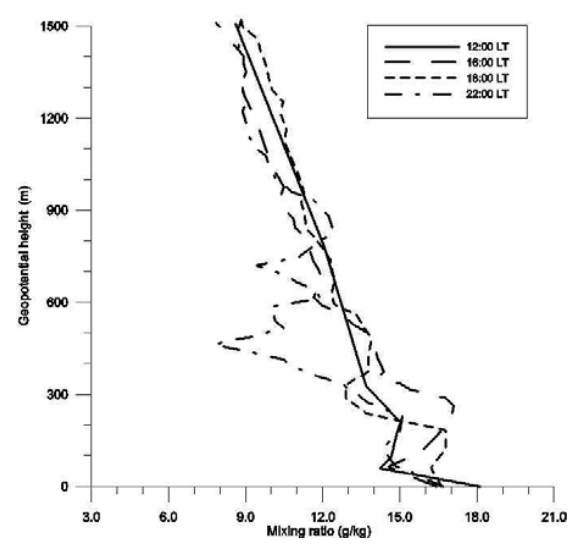

(b)

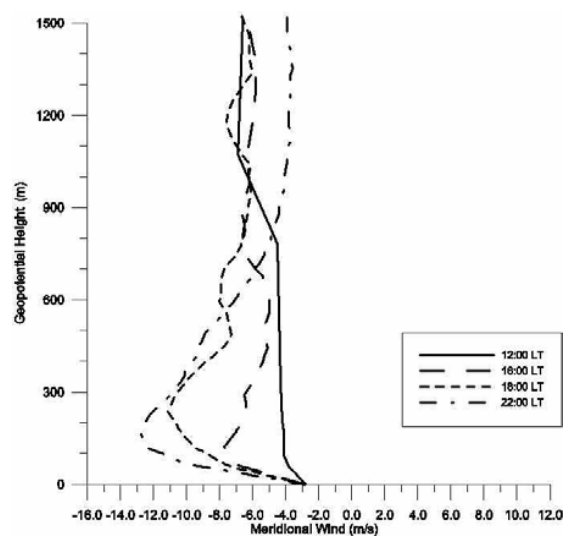

(d)

Fig. 3. Vertical profiles of: (a) virtual potential temperature $\left(\theta_{v}\right),(\mathbf{b})$ mixing ratio $\left(\mathrm{r}_{w}\right)$, (c) zonal wind (u), and (d) meridional wind (v) component, respectively, on 9 January 1995. 


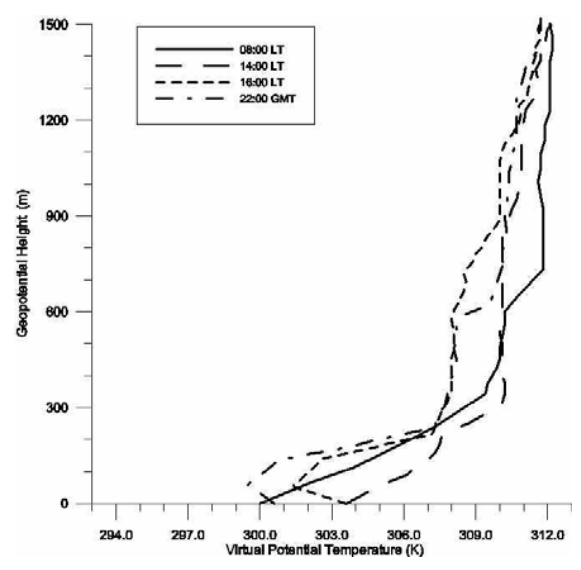

(a)

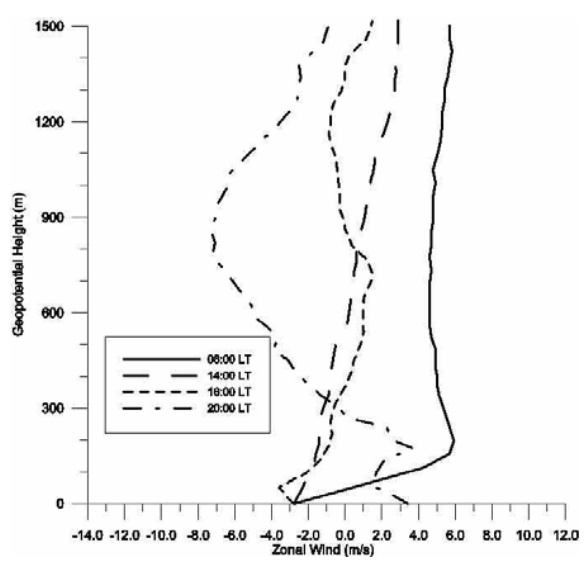

(c)

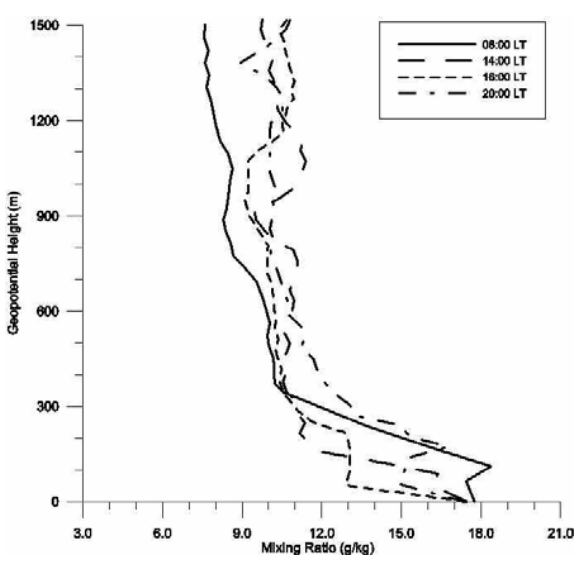

(b)

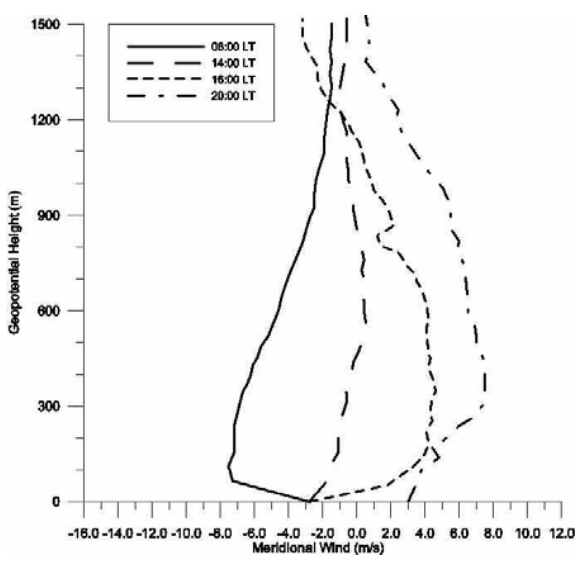

(d)

Fig. 4. Same as in Fig. 3, but for 10 January 1995.

land, the descending motion was weaker, allowing for vertical mixing. Also, the LLJ may provoke a turbulent mixing of the air in the lower layers, favouring the development of a nocturnal mixed layer. From Fig. 3b, it can be noted that there was a strong vertical gradient of $r_{w}$ from the surface to $50 \mathrm{~m}$, which is a characteristic of marine air layers. At low levels the values of $r_{w}$ were slightly higher at 16:00 LT and 18:00 LT. This was due to the moisture advection by the seabreeze circulation. At 22:00 LT there was a minimum of $r_{w}$ just above LLJ level (around $450 \mathrm{~m}$ ).

The values of SST on 10 January 1995 were within the limits of SACW (Table 2). However, the synoptic conditions were modified by the entrance of a cold front, as mentioned in Sect. 3. At 08:00 LT a stable atmosphere was observed, as showed in Fig. 4a. Between 14:00 LT and 16:00 LT the temperature at the surface was almost the same. However, at 16:00 LT, due to the cold advection by the southerly wind there was a cooling in the layer above. From the surface to
$300 \mathrm{~m}$ the cooling was stronger, leading to the formation of an unstable layer in the first $100 \mathrm{~m}$. Between 16:00 LT and 20:00 LT there was an increase in the cooling in the layer from the surface to $300 \mathrm{~m}$, but the unstable layer near the surface was maintained. Due to the presence of the cold front the values of the mixing-ratio increased when compared with those of the day before (see Figs. $4 \mathrm{~b}$ and $3 \mathrm{~b}$ ). Also, the vertical profiles of the zonal wind showed a weaker sea breeze (see Fig. 4c and Fig. 3c). The entire vertical profile of the meridional wind was from the north until 14:00 LT. Because of the passage of the cold front there was a change in the direction of the meridional wind, so that the southeasterly winds increased from 16:00 LT to the last sounding. At 20:00 LT the entire vertical profile of the meridional wind was from south.

Starting from 11 January 1995 the SST increased and the alterations in the vertical structure of the atmosphere were not representative of an upwelling situation. Although the 


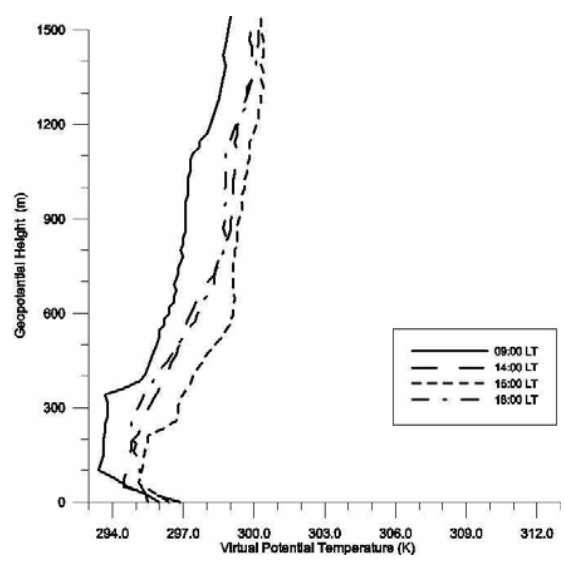

(a)

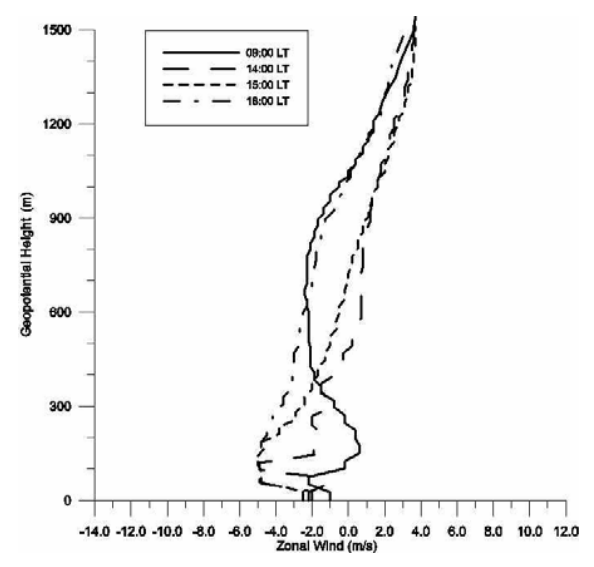

(c)

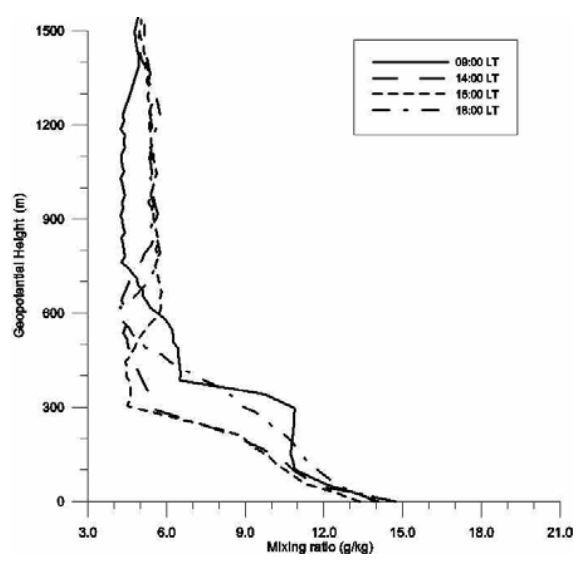

(b)

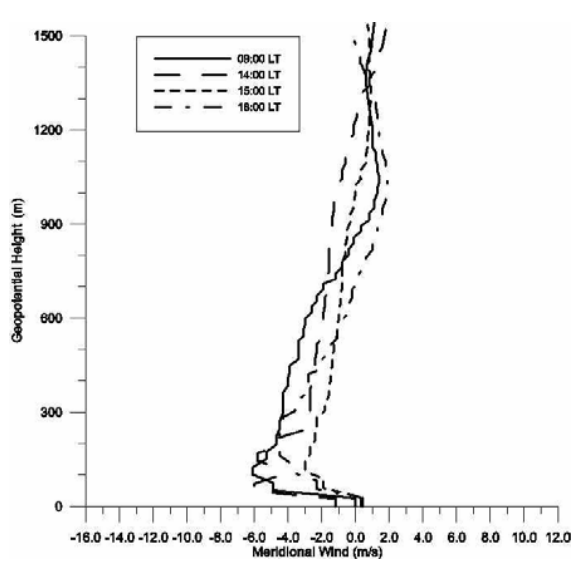

(d)

Fig. 5. Same as in Fig. 3, but for 6 August 1996.

mean water temperature was not too much higher than that of the day before (see Table 2), the vertical profiles of the winds and the virtual potential temperature were greatly changed because of the cold front passage. The easterly zonal wind was weak (highest value equal to $3 \mathrm{~m} \mathrm{~s}^{-1}$ at 15:00 LT) and the prevailing winds were from the southwest in the other three soundings (at 17:00 LT, 19:00 LT and 21:00 LT) (figures not shown). During the first sounding on 12 January 1995 (at 08:00 GMT), the weather was cloudy, with light showers, due to the influence of the cold front. This provoked an increase in the water temperature (Table 2) and the occurrence of a less stable atmosphere compared with the day before. The zonal and meridional winds were weaker compared with those in the earlier days and the vertical profiles of $\theta_{v}$ showed a formation of a mixed layer (figures not shown).

\subsection{Non-upwelling case}

In this part the evolution of the ABL is examined using the radiosounding data collected from 5 to 9 August 1996. In the first sounding of this experiment (day 5 August 1996, 19:00 LT) there was a mixed layer up to $200 \mathrm{~m}$; the zonal winds were from west, except near the surface, and the meridional winds were from the north up to $150 \mathrm{~m}$, blowing from the south above this level (figures not shown). On 6 August 1996 at low levels the easterly zonal wind component increased during the afternoon, indicating an enhancement of the sea-breeze circulation. The stronger easterly winds $\left(5.0 \mathrm{~m} \mathrm{~s}^{-1}\right)$ occurred around 18:00 LT (Fig. 5c). As seen in Fig. 5a, a mixed layer with $350 \mathrm{~m}$ was present at 09:00 LT. This mixed layer was reduced in the next two soundings (14:00 LT and 15:00 LT) and increased again at 18:00 LT. Above $700 \mathrm{~m}$ there was little variation of the humidity during the afternoon and the beginning of the night (Fig. 5b). 


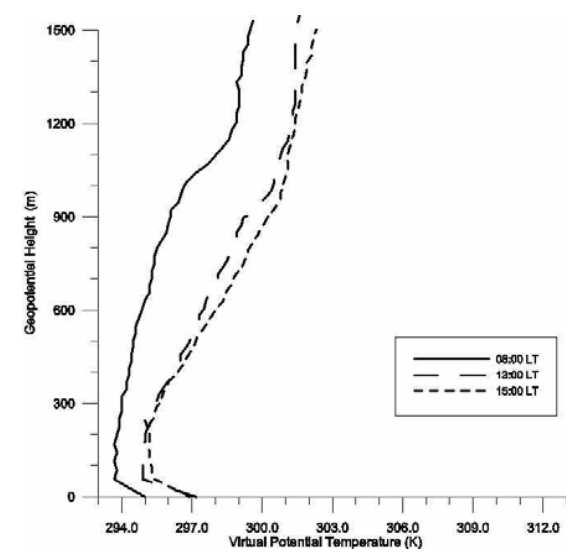

(a)

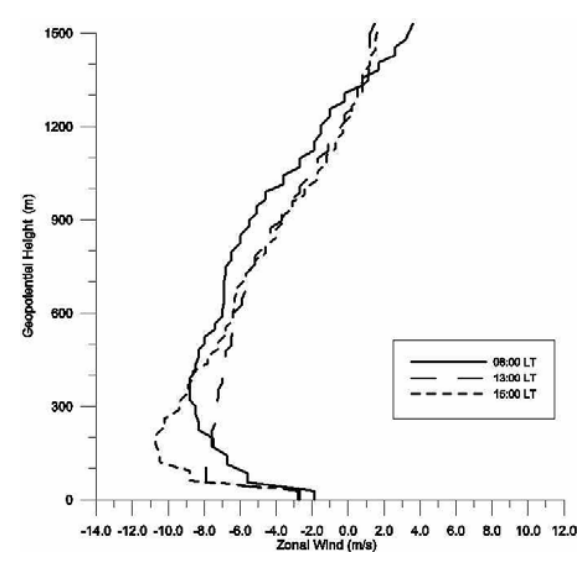

(c)

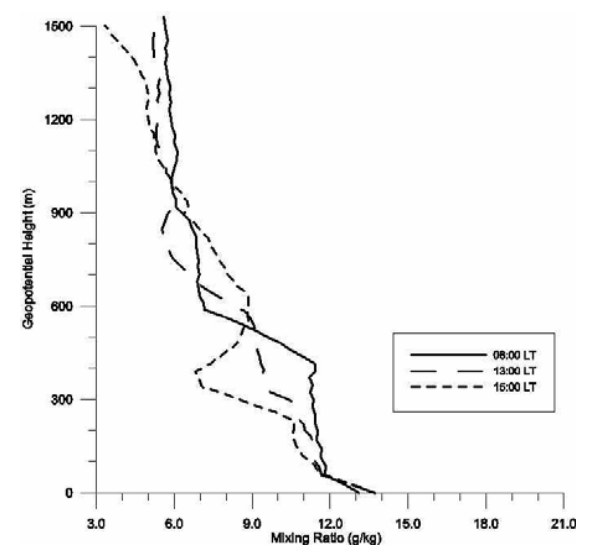

(b)

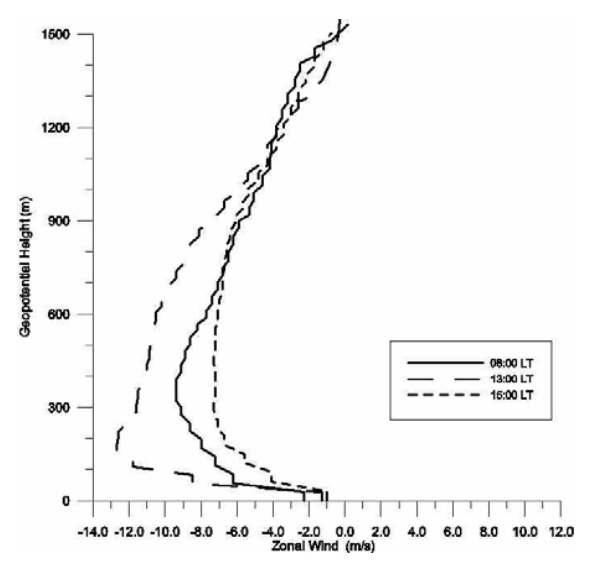

(d)

Fig. 6. Same as in Fig. 3, but for 7 August 1996.

On the next day (7 August 1996), from 08:00 LT to 13:00 LT, there was a marked warming of the air in the entire ABL and between 13:00 LT and 15:00 LT the vertical profiles of $\theta_{v}$ showed little variation (Fig. 6a). It can be noted in all the $\theta_{v}$ vertical profiles that there was an occurrence of a mixed layer in the low levels below $350 \mathrm{~m}$. As shown in Fig. $6 \mathrm{~b}$, the values of $\mathrm{r}_{w}$ were almost the same up to around $300 \mathrm{~m}$. At 15:00 LT the easterly zonal winds were around $10.5 \mathrm{~m} \mathrm{~s}^{-1}$ (Fig. 6c). As can be noted in Fig. 6d, the meridional wind was from the north in the entire ABL in all the soundings of the day.

On 8 August 1996 there was a warming of the air in the whole ABL from 06:00 LT to 09:00 LT (Fig. 7a). This warming continued until 12:00 LT above $300 \mathrm{~m}$. From 12:00 LT to 15:00 LT a small increase in the temperature was observed and later there was a cooling of the ABL. The values of $r_{w}$ showed a minimum between 12:00 LT and 15:00 LT, as seen in Fig. 7b. Again, a mixed layer was observed below $350 \mathrm{~m}$ during the day. Figure $7 \mathrm{c}$ shows that the zonal wind was from the east in all the soundings, except at 15:00 LT and 18:00 LT, above $800 \mathrm{~m}$. These westerly zonal winds may be associated with the return flow of the sea-breeze circulation. The strongest easterly winds $\left(9.6 \mathrm{~m} \mathrm{~s}^{-1}\right)$ occurred at 20:00 LT. As shown in Fig. 7d, the meridional winds were from the north in most of the ABL.

On 9 August 1996 there was a stable layer between 500 and $1000 \mathrm{~m}$, which gradually reduced during the day, as shown in Fig. 8a. At 13:00 LT a mixed layer was observed below $350 \mathrm{~m}$. Like in the previous days, this mixed layer was reduced in the subsequent soundings. Although the $\mathbf{r}_{w}$ curve showed an inflection point around $350 \mathrm{~m}$, the mixing ratio was almost constant up to $600 \mathrm{~m}$ in all the soundings (Fig. 8b) associated with the advection of marine air over land. From $600 \mathrm{~m}$ to $900 \mathrm{~m}$ there was a sharp decrease in $\mathrm{r}_{w}$ during the day and above this level a little variation of the humidity was noted. The diurnal march of the zonal wind 


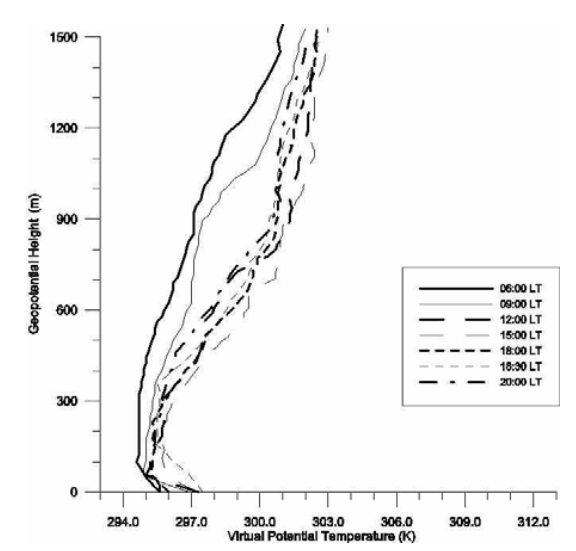

(a)

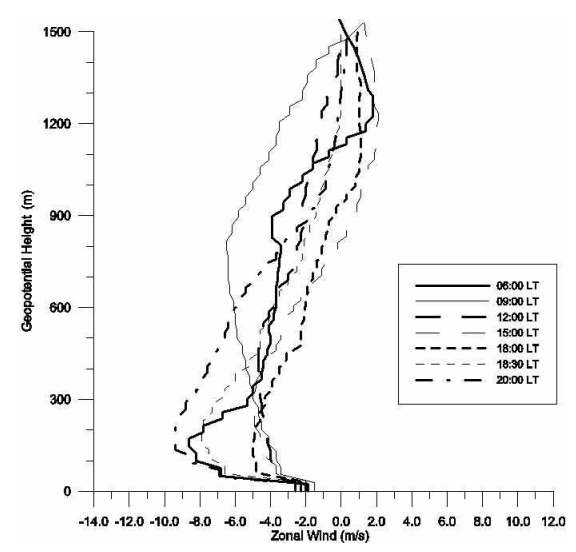

(c)

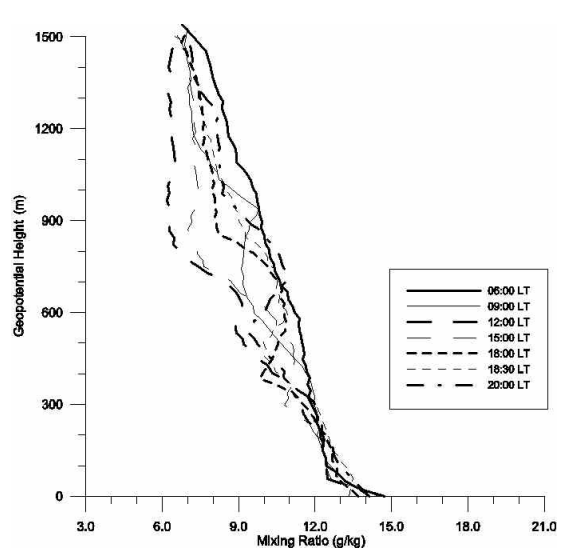

(b)

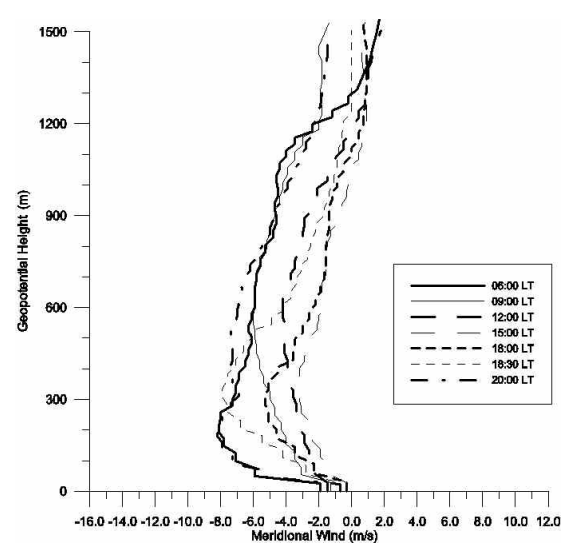

(d)

Fig. 7. Same as in Fig. 3, but for 8 August 1996.

showed an increase in the easterlies near the surface, illustrating the sea-breeze development (Fig. 8c). The strongest easterly winds $\left(9.0 \mathrm{~m} \mathrm{~s}^{-1}\right)$ occurred at 17:00 LT. As seen in Fig. 8d, the meridional winds were from the north in the entire $\mathrm{ABL}$ in all the soundings. However, the diurnal variation of $\mathrm{v}$ was much lower compared with that of the zonal wind.

Comparing the vertical profiles of the zonal wind during 9 January 1995 (typical upwelling condition) (Fig. 3c) with those during 5-9 August 1996 (no upwelling conditions) (Figs. 5c, 6c, 7c, and 8c) it can be clearly seen that the upwelling increased the sea-breeze signal. These results confirm model simulations, which show that the sea-breeze is stronger during the spring and summer months (upwelling conditions) (see Figs. 12b, 14 and 15 of Franchito et al., 1998), and are in agreement with surface observational data from the Meteorological Station at Cabo Frio (see Figs. 11 and 12a of Franchito et al., 1998).

\section{Summary and conclusions}

This work investigates the influence of the coastal upwelling on the evolution of the ABL in the Cabo Frio region. For this purpose we collected radiosonde data in two field experiments made during the austral summer (upwelling case) and austral winter (no upwelling case). The first one took place during 9-12 January 1995, and the second experiment during 5-9 August 1996. Both the experiments were part of the COINT project (FAPESP, No. 93/0854-4).

The results showed that the higher differences in the evolution of the ABL in the two cases are related to the differences in the atmospheric stability and local winds. During the austral summer, cold waters near the Cabo Frio coast contributed to the formation of an atmospheric stable layer, which persisted during the upwelling episode. Due to the low SSTs the descending branch of the sea-breeze circulation was located close to the coast, inhibiting the development of an air mixed layer mainly during the day. During the night, since 


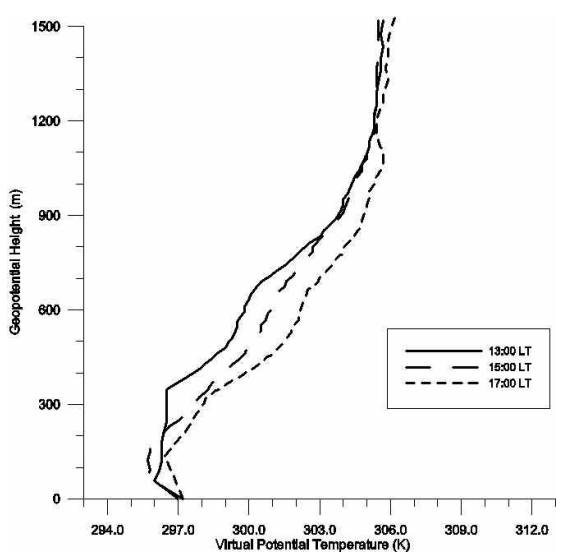

(a)

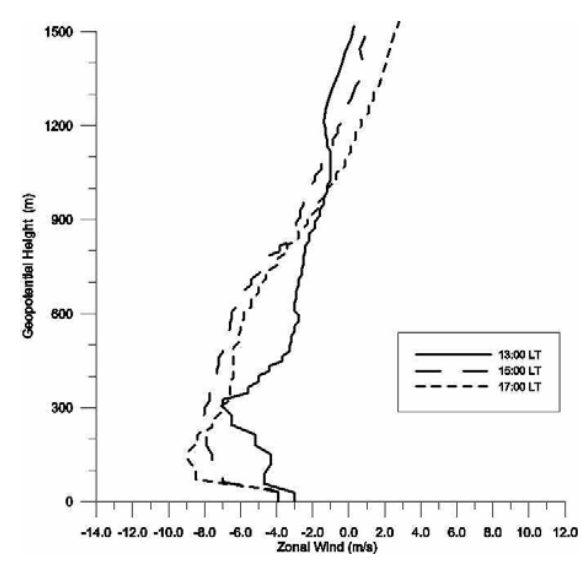

(c)

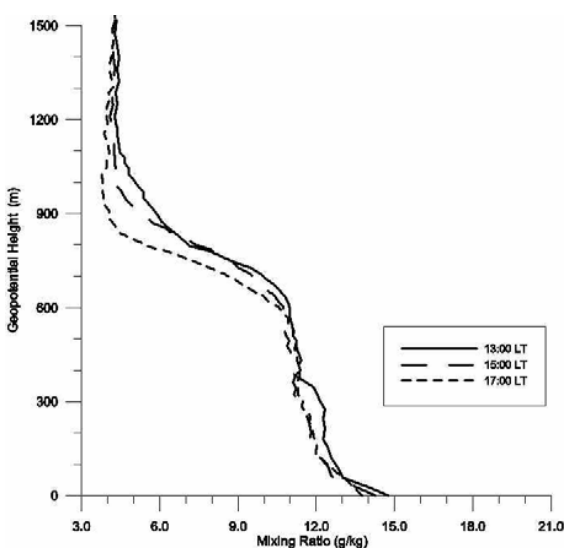

(b)

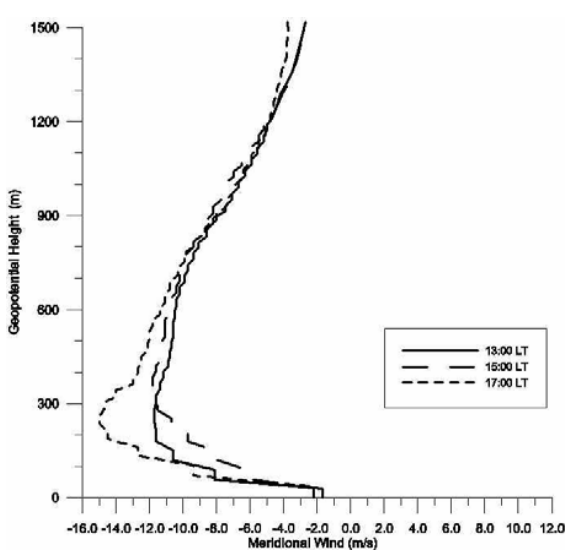

(d)

Fig. 8. Same as in Fig. 3, but for 9 August 1996.

the land-sea thermal contrast was reduced the sea-breeze circulation (and consequently its descending branch) was weakened. Thus, the mixed layer formed mainly at night. In addition, as expected the stable ABL favoured the formation of LLJs (Blackadar, 1957), which, in turn, contributed to the development of a nocturnal atmospheric mixed layer. During the austral winter, due to the higher SSTs observed near the coast, the ABL was less stable compared with that in the austral summer. Because of the warming a mixed layer was observed during the day in the soundings in the no-upwelling case.

The vertical profiles of the zonal winds showed that the easterlies at low levels were stronger in the upwelling case, indicating that the upwelling modulates the sea-breeze signal. This confirms model simulations and is in agreement with surface observational data from the Meteorological Station at Cabo Frio.

Acknowledgements. The two field experiments were supported by Fundação de Amparo à Pesquisa do Estado de São Paulo (FAPESP,
No. 93/0854-4). The authors are thankful to M. S. Dourado for his help in collecting data.

Topical Editor F. D'Andrea thanks two anonymous referees for their help in evaluating this paper.

\section{References}

Blackadar, A. K.: Boundary layer wind maxima and their significance for the growth of nocturnal inversions, B. Am. Meteor. Soc., 38, 383-290, 1957.

Campos, E. J. D., Gonçalvez, J. E., and Ikeda, Y.: Water mass characteristics and geostrophic circulation in the South Brazil Bight: summer of 1991, J. Geophys. Res., 100(C9), $18537-$ $18550,1995$.

Carbonel, C. A. A. H.: Modelling the upwelling-downwelling cycles caused by variable Wind in a very sensitive coastal system, Cont. Shelf. Res., 23, 1559-1578, 2003.

Castelao, R. M., Campos, E. J., and Miller, J. L.: A modelling study of the coastal upwelling driven by wind and meanders of 
the Brazil current, J. Coastal Res., 20, 662-671, 2004.

Castelao, R. M. and Barth, J. A.: Upwelling around Cabo Frio: The importance of wind stress curl, Geophys. Res. Lett., 33, L03602, doi:10.1029/2005GL025182, 2006.

David G. S., Coutinho, R., Quagio-Grassiotto I, I., and Verani, J. R.: The reproductive biology of Dyplodus argenteus (Sparidae) in the coastal upwelling system of Cabo Frio, Rio de Janeiro, Brazil, African J. Marine Sci., 27, 439-447, 2005.

De Leo, F. C. and Pires-Vanin, A. M. S.: Benthic megafauna communities under the influence of the South Atlantic Central Water intrusion onto the Braziilian SE shelf: A comparison between an upwelling and a non-upwelling ecosystem, J. Marine Systems, 60, 268-284, 2006.

Dourado, M. S. and Oliveira, A. P.: Observational study of the atmospheric and oceanic boundary-layer over the Atlantic ocean, Rev. Bras. Oceanogr., 49, 49-59, 2000.

Franchito, S. H., Rao, V. B., Stech, J. L., and Lorenzzetti, J. A.: The effect of coastal upwelling on the sea-breeze circulation at Cabo Frio, Brazil: a numerical experiment, Ann. Geophys., 16, 866-881, 1998, http://www.ann-geophys.net/16/866/1998/.

Gaeta, S. A., Brino, O. L., and Ribeiro, S. M. M. S.: Distributions of nitrate, chlorophyll $a$, and primary productivity in the southwestern region of the South Atlantic during summer, Southwestern Atlantic Physical Oceanography Workshop, edited by: Campos, E., pp.57-60, 1994.

Gonzalez-Rodriguez, E., Valentin, J. L., André, D. L., and Jacob, S. A.: Upwelling and downwelling at Cabo Frio (Brazil): a comparison of biomass and primary production responses, J. Plank. Res., 14, 289-306, 1992.
Laslands, B., Sylvestre, F., Siffedine, A., Turcq, B., Albuquerque, A. L. S., and Abrão, J.: Hydroclimatic variability record from the Cabo Frio coast (Rio de Janeiro, Brazil) during the last $6500 \mathrm{yr}$, Comptes Rendus Geosc., 338, 667-675, 2006.

Matsuura, Y.: Brazilian sardine (Sardinella brasiliensis) spawning in the southeast bight over the period 1976/93, Revista Brasileira de Oceanografia, 46, 33-43, 1998.

Matsuura, Y.: A probable cause of recruitment failure of Brazilian sardine (Sardinella aurita) population during the (1974/75) spawning season, South African J. Mar. Sci., 17, 29-35, 1996.

Rodrigues, R. R. and Lorenzzetti, J. A.: A numerical study of the effects of bottom topography and coastline geometry on the Southeast Brazilian coastal upwelling, Cont. Shelf. Res., 21, 371-394, 2001.

Stech, J. L. and Lorenzzetti, J. A.: The response of the South Brazil Bight to passage of the winter time cold fronts, J. Geophys. Res., 97(C6), 9507-9520, 1992.

Valentin, J. L., André, D. L., and Jacob, S. A.: Hydrobiology in the Cabo Frio (Brazil) upwelling: two-dimensional structure and variability during a wind cycle, Cont. Shelf Res., 7, 77-88, 1987.

Valentin, J. L.: Analyses des parameters hydrobiologiques dans la remontée de Cabo Frio (Brésil), Mar. Biol., 82, 259-276, 1984.

Voloch, C. M. and Sole-Cava, A. M.: Genetic structure of the sea-bob shrimp (Xiphopenaeus kroyeri Heller, 1862; Decapoda, Penaeidae) along the Brazilian southeastern coast, Genet. Mol. Biol., 28, 254-257, 2005. 